\title{
Perception Based Assessment of Ecosystem Services of Madhupur Sal Forest in Bangladesh
}

\author{
Soumitra Saha, Shaikh Shamim Hasan, Md. Enamul Haque, and Tofayel Ahamed
}

\section{ABSTRACT}

\begin{abstract}
Madhupur Sal (Shorea robusta) forest, the largest belt of natural Sal forest in Bangladesh, is rich in ecological resources and biodiversity. In recent years, human disturbance leads to biodiversity loss from the forest, and it has a successive effect on the services that the forest provides. Thus, it is crucial to explore the present condition of the forest's available ecosystem services with local people's consciousness about the ecosystem. The present study investigated the available ecosystem services of Madhupur Sal forest, respondents' perception towards those services and the socio-demographic characteristics of the respondents that influenced their perception. Data were collected by interviewing 90 respondents with a focus group discussion. Most of the respondents in the study area were ethnic people (Garo). A total of 20 ecosystem services were identified where soil erosion control, mental peace and maintenance of soil fertility were the top-ranked services. About $83 \%$ of the respondents had moderately favorable perception towards ecosystem services. The study results showed that the respondents with a higher level of education, higher family annual income, and more training received on agriculture perceived ecosystem services to a greater extent than others. So, improvement of their perception towards ecosystem services can make them aware of forest biodiversity conservation.
\end{abstract}

Keywords: Ecosystem Services, Madhupur, Bangladesh, Perception, Sal Forest.

\author{
Published Online: January 15, 2021 \\ ISSN: $2684-1827$ \\ DOI: 10.24018 /ejfood.2021.3.1.194 \\ Soumitra Saha \\ Dept. of Agril. Extn. \& Rural Devt., \\ BSMRAU, Gazipur, Bangladesh. \\ (e-mail: soumitra.saha56@bsmrau.edu.bd) \\ Shaikh Shamim Hasan * \\ Dept. of Agril. Extn. \& Rural Devt., \\ BSMRAU, Gazipur, Bangladesh. \\ (e-mail: shamim.aer@bsmrau.edu.bd) \\ Md. Enamul Haque \\ Dept. of Agril. Extn. \& Rural Devt., \\ BSMRAU, Gazipur, Bangladesh. \\ (e-mail: denamul_2008@yahoo.com). \\ Tofayel Ahamed \\ Dept. of Agroforestry \& Environment, \\ BSMRAU, Gazipur, Bangladesh. \\ (e-mail: tofayela ${ }^{@}$ gmail.com). \\ *Corresponding Author
}

\section{INTRODUCTION}

Natural ecosystems contribute to human welfare by offering different types of services that are crucial to their survival [1]. Forests are the harbor of immense terrestrial and aquatic biodiversity, provide environmental services that are fundamental for the Earth's life support systems [2]. They provide a vast array of ecosystem services such as timber production, non-timber forest products, maintenance of water supply and quality, carbon sequestration, climate change mitigation and adaptation, biodiversity conservation, etc. Besides, forests are the host of various social, cultural, spiritual, aesthetic, recreational, and educational benefits [3], [4]. However, in recent years, sustaining ecosystem services has become a major challenge in a rapidly changing world. Despite this recognized function of forests in maintaining livelihoods, deforestation is continuing at a rapid pace worldwide. Human societies are altering ecosystems locally and globally. The rapid rate of global environmental change makes it continuously difficult for the biotic world to adapt [3], [5].

Any benefits that humans acquire from ecosystems, either directly or indirectly are recognized as ecosystem services [6]. While some of the benefits are tangible (food, fuel, or timber), other benefits like soil erosion control, climate control, pollination by native bees, or, nutrient cycling have been hardly acknowledged [7]. The international program, namely Millennium Ecosystem Assessment (MEA), evaluated the effect of ecosystem change on human day to life. It [8] showed the connection between the livelihoods of people and ecosystem services. It found that the deterioration of ecosystem services negatively affected the livelihood of people [9]. According to [8], the ecosystem services are those that provide several benefits to the people and are primarily grouped into provisioning (tangible products like food fiber, timber, fuel, etc.), regulating (regulates the natural phenomena like soil erosion control, maintenance of soil fertility, protection from extreme natural events, etc.), supporting (enables other services to function like primary production, soil formation, nutrient cycling, etc.), and cultural services (intangible benefits that include recreational, spiritual, cognitive development, or aesthetic experiences, etc.).

This article focuses on the local peoples' perception towards Madhupur Sal forest's ecosystem services of Tangail district. According to [10], local people's perception towards ecosystem services is important not only for evaluating the socio-cultural dimension of ecosystem services but also for assuring the behavioral compliance with management and policies. The Madhupur Sal forest (also known as Madhupur Garh) is an attractive area located in Dhaka division of Bangladesh, landform is Pleistocene terrace, placed between the river Bangshai in the west and Banar in the east [11]. The Garh is a northern part of the Madhupur tract, and situated a few meters above the surrounding flood plains; $36 \%$ of the forest coverage declined during the years of 1975 to 1983 
[12]. Generally, forest can supply all major ecosystem services from provisioning to cultural. The forest aids forestdwellers for meeting their daily needs since ancient times. The forest communities support a wide array of threatened species, including the disappeared species. In recent days, social and religious values related to the forest have declined mostly due to technological development and urbanization [13].

Madhupur Sal forest, also the third-largest forest of Bangladesh, once housed numerous species, including different fruit trees, vegetables, medicinal plants, various herbs, and creepers. Now, most of it has been converted into gardens of banana, pineapple, rubber, fuelwood, turmeric, and papaya. Over the last two and a half decades, forest land has experienced massive environmentally harmful changes. The natural forest vanished along with its rich biodiversity, causing inestimable and possibly persistent loss to the environment. The Forest Department has sown the alien and invasive species in the forest area, mostly eucalyptus and acacia, by clearing of Sal trees [12].

The loss of the natural forest has also devastated the life and livelihood of the ethnic people (Garo) of the forest. The 'Garos' have been deemed the earliest dweller of the Madhupur, and originally migrated from Tibet. The Garos have a matrilineal society; women are the main bread earner who mostly exploit the forest's biological resources. But the destruction of the indigenous Sal forest, which has become intense after the liberation war of Bangladesh, has made their task complicated [14]-[16].

Until the beginning of the 20th century, this forest remained as a large continuous belt with rich biodiversity, but increasing pressure has been placed on them due to the rapid population growth. Encroachers have occupied most of the forest area [17]. So, the services that the forest in the early days offered to the local public are on the way to deterioration. Researches on the Madhupur Sal forest have emphasized mainly on conservation [11], [18] and ecology [19], [20] of the ecosystem. Perception-based assessment of the ecosystem services of the Madhupur Sal forest has not been conducted yet. Even no studies have been carried out on the ecosystem services of this Sal forest. So, the available ecosystem services of the forest are still unexplored. Bearing the above situation in mind, a study was performed to find out the present status of ecosystem services of that forest and to determine the perception of the respondents towards the ecosystem services. The following objectives were set to lead the study:

1. To identify the ecosystem services in the Madhupur Sal forest and perception of the respondents towards those services.

2. To determine the sociodemographic characteristics of the respondents as well as the contribution of those characteristics towards their perception of the ecosystem services.

\section{Methodology}

\section{A. Research Design}

The descriptive survey research design was followed in this study. A focus group discussion was carried out to identify the ecosystem services. In person interview method with a semi-structured interview schedule was used to collect data from the respondents. The respondents were selected from the three villages of Madhupur Upazila of Tangail district. All the respondents of three villages whose livelihood strategy directly or indirectly associated with the Sal forest were the population of the present study. The total number of respondents of the three villages was 764. Out of them, 90 respondents were selected as a sample through a proportionate random sampling technique. The data collection process was completed within December 2019 to March 2020.

\section{B. Measurement of Dependent Variables}

The perception of the respondents towards ecosystem services was the dependent variable of this study. A fivepoint Likert type scale, consisting of 21 statements on ecosystem services was used to measure respondents' perception towards ecosystem services. Among the statements, 14 were positive and 07 were negative. Reverse scoring was assigned for negative statements. Score 5, 4, 3, 2 , and 1 was assigned for strongly agree, agree, undecided, disagree and strongly disagree statements respectively. Same scale was used in the studies of [21]-[26].

To get respondents' perception score towards ecosystem services, individual scores of 21 statements were added together. Thus, the perception score of a respondent could range from 21 to 105, where 21 indicating 'very low perception' and 105 indicating 'very high perception'. By using the formula of mean $\pm \mathrm{SD}$, the respondents' perception scores were categorized into less favorable (up to 58), moderately favorable (58 to 68) and highly favorable perception (more than 68).

\section{Measurement of Independent Variables}

The independent variables of the present study were gender, age, family size, level of education, land ownership, farm size, family annual income, extension media contact, and training received on agriculture.

Age of a respondent was assessed based on the actual age of his life and expressed in years. Family size was measured by the total number of members, including the respondent himself, spouse, children and other members who jointly lived. The education was measured by the number classes completed. Land ownership was measured by the total land area owned by the respondents. The farm size included the lands used for the maintenance of farming enterprise(s) by a respondent and it was expressed in acres. The family annual income of a respondent was estimated based on his total annual earnings from service, business agriculture, and other sources. The extension media contact scores of the respondents were computed based on their extension contact with different sources of information. The training was measured by the total number of agriculture-related training a respondent experienced from different organizations.

For data analysis, Statistical Package for Social Science (SPSS) was used and statistical tests like frequency count, percentage, mean, standard deviations were performed. Multiple regression analysis was used for exploring the factors that contribute to respondents' perception and 0.05 and 0.01 level of probabilities were used as a basis for exploring the association between the dependent and independent variables. 


\section{RESUlTS AND DisCUSSION}

\section{A. Identification of Ecosystem Services}

A focus group discussion (FGD) was carried out at the community level at the Pirgacha village of Madhupur Upazila with ten participants to identify the ecosystem services. The focus group participants were selected based on their livelihood strategy and dependency on the Sal forest. To make it effective, it was ensured that all the participants willingly engaged in the discussion and a local leader acted as a moderator during the discussion session. A total number of 20 ecosystem services were identified through FGD. Among them, eleven were in provisioning, four in cultural, three in regulating, and two in supporting ecosystem services categories (Fig. 1).

All of the services except crop cultivation showed decreasing trend due to rapid population growth, encroachment of the forest areas, industrialization, urbanization, monocropping practice, and pollution.

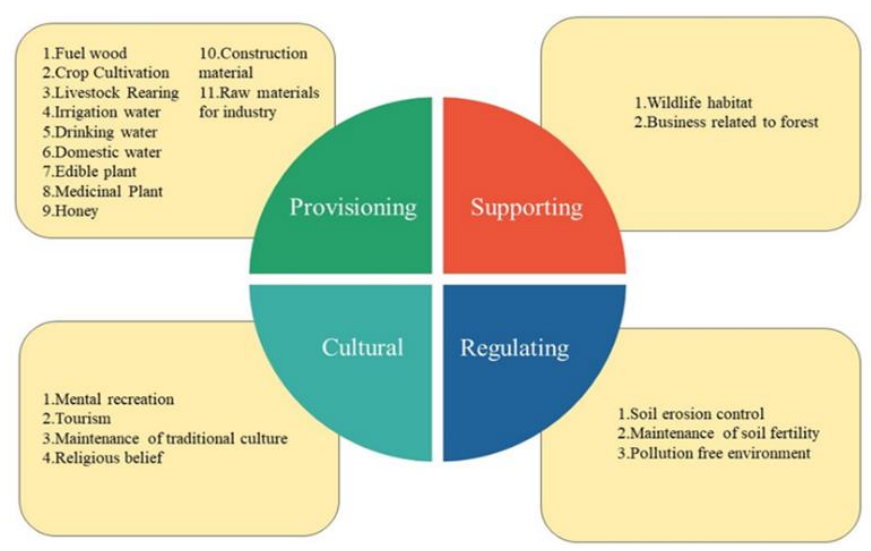

Fig. 1. Ecosystem services identified in the study area.

\section{B. Perception towards Ecosystem Services of Madhupur Sal Forest}

Data presented in Table I indicated that the respondents had top most perception towards ecosystem services in respect of 'I think the forest enhances mental serenity' was the highest (Score=212) followed by 'I think the forest maintains environmental equilibrium' (Score=209), and 'In my opinion, the forest protects us from natural disasters.' (Score=207). From the three top-ranked statements, it can be said that the respondents were mostly satisfied with the cultural and regulating services of the forest. According to them, the forest environment was congenial to mental health. Besides, by reducing pollution, forest protected the local community from extreme environmental hazards and maintained ecological balance.

The respondents also had negative perception on some statements. The statements 'I make a profit by selling forest products' (Score=74) ranked 21st, 'I collect water from the forest ditch for drinking, domestic use and irrigation purpose' $($ Score $=80)$ ranked 20th, and 'I collect construction material and raw materials for industry from the forest' (Score=81) ranked 19th in total score. The respondents of the study area disagreed with these statements. These statements revealed that the respondents were not satisfied with the provisioning services of the Madhupur Sal forest ecosystem. Intensive deforestation, urbanization, industrialization in the forest area negatively affected the provisioning services of the forest.
Due to strict govt. restriction, they hardly had access to forest to collect the forest products. Besides, there was no profitable market place for selling forest products in the study area. Tourists were the main clients of forest products. But in recent years, tourist activity decreased in the forest area due to the loss of unique features of the forest.

From Table II, it is obvious that highest proportion of the respondents $(82.40 \%)$ had moderately favorable perception towards ecosystem services followed by highly favorable perception $(9.80 \%)$. Thus, the findings revealed that a major portion of the respondents $(92.20 \%)$ in the study area had moderately favorable to highly favorable perception towards ecosystem services.

TABLE I: RANK ORDER OF THE STATEMENTS ACCORDING TO RESPONDENTS' PERCEPTION TOWARDS ECOSYSTEM SERVICES

\begin{tabular}{|c|c|c|c|}
\hline S1. & Statements & Score & Rank \\
\hline & Provisioning services & & \\
\hline 01 & I am dependent on Sal forest for livelihood (+) & 92 & 17 \\
\hline 02 & $\begin{array}{l}\text { In my opinion, the forest does not provide me } \\
\text { different sorts of crops, vegetables, medicinal } \\
\text { plants (-) }\end{array}$ & 158 & 11 \\
\hline 03 & I collect fuelwood from the forest $(+)$ & 134 & 13 \\
\hline 04 & I never collect animal feed from the forest (-) & 94 & 16 \\
\hline 05 & $\begin{array}{l}\text { I collect water from the forest ditch for } \\
\text { drinking, domestic use, and irrigation purpose } \\
(+)\end{array}$ & 80 & 20 \\
\hline 06 & $\begin{array}{l}\text { I collect construction material and raw } \\
\text { materials for industry from the forest }(+)\end{array}$ & 81 & 19 \\
\hline & Cultural services & & \\
\hline 07 & $\begin{array}{l}\text { There is no relationship between the forest with } \\
\text { my religion (-) }\end{array}$ & 116 & 14 \\
\hline 08 & $\begin{array}{l}\text { I think there is ample potentiality in the } \\
\text { development of tourism in the forest }(+)\end{array}$ & 196 & 7 \\
\hline 09 & $\begin{array}{l}\text { I collect the flower, fruits from the forest for } \\
\text { worshipping }(+)\end{array}$ & 88 & 18 \\
\hline 10 & I think the forest enhances mental serenity $(+)$ & 212 & 1 \\
\hline 11 & $\begin{array}{l}\text { I think there is no potentiality of education and } \\
\text { research in the forest (-) }\end{array}$ & 170 & 10 \\
\hline 12 & $\begin{array}{l}\text { I think the forest helps to sustain the tradition } \\
\text { and culture of the Garo community }(+) \\
\text { Regulating services }\end{array}$ & 200 & 5 \\
\hline 13 & $\begin{array}{l}\text { I think the forest maintains environmental } \\
\text { equilibrium }(+)\end{array}$ & 209 & 2 \\
\hline 14 & I think the forest area is pollution free $(+)$ & 196 & 6 \\
\hline 15 & $\begin{array}{l}\text { I think the forest soil is very fertile and nutrient } \\
\text { cycle works properly }(+)\end{array}$ & 188 & 9 \\
\hline 16 & $\begin{array}{l}\text { I think the rainfall and seasonal cycle do not } \\
\text { follow a regular pattern }(-)\end{array}$ & 98 & 15 \\
\hline & Supporting services & & \\
\hline 17 & $\begin{array}{l}\text { In my opinion, the forest protects us from } \\
\text { natural disasters }(+)\end{array}$ & 207 & 3 \\
\hline 18 & $\begin{array}{l}\text { I think the forests is the sanctuary of plenty of } \\
\text { wild animals }(+)\end{array}$ & 146 & 12 \\
\hline 19 & $\begin{array}{l}\text { There is no restriction on my collection of } \\
\text { forest products (-) }\end{array}$ & 204 & 4 \\
\hline 20 & I make a profit by selling forest products $(+)$ & 74 & 21 \\
\hline 21 & $\begin{array}{l}\text { In my view, there is no demand for forest } \\
\text { products in the local market (-) }\end{array}$ & 195 & 8 \\
\hline
\end{tabular}

TABLE II: DISTRIBUTION OF THE PERCEPTION OF THE RESPONDENTS TOWARDS ECOSYSTEM SERVICES

\begin{tabular}{ccccc}
\multicolumn{5}{c}{ TOWARDS ECOSYSTEM SERVICES } \\
\hline Categories & Frequency & $\%$ & Mean & SD \\
\hline $\begin{array}{c}\text { Less favorable perception } \\
\text { (score less than 58) }\end{array}$ & 7 & 7.80 & & \\
$\begin{array}{c}\text { Moderately favorable } \\
\text { perception (score 58-68) }\end{array}$ & 74 & 82.40 & 61.53 & 5.17 \\
$\begin{array}{c}\text { Highly favorable perception } \\
\text { (score more than 68) } \\
\text { Total }\end{array}$ & 9 & 9.80 & & \\
\hline
\end{tabular}

Most of the respondents (Garo) of the present study were forest inhabitants. They had been living in the forest for a long time. Thus, a long-lasting close relationship built between the 
Garos and the forest. Dependency on forest for livelihood shaped their distinct societal structure and cultural practices. These made them much aware of forest resource conservation. Similar findings were witnessed by [13]. They found that forest dwellers perceived ecosystem services better than urban people. Besides, Christian missionaries worked in the Madhupur forest area for the welfare of the ethnic people. They promoted educational facilities in the remote areas of the forest. Education made them more conscious of the significance of the forest ecosystem. These factors ultimately contributed to perceive forest ecosystem services to a greater extent.

\section{Socio-demographic Characteristics of the Respondents}

Majority of the respondents in the study were ethnic minorities (Garos). Data presented in Table III revealed that most percentage of the respondents $(79 \%)$ of the study area were male while the remaining were female. The more than 50 years of age category constituted the highest proportion of the respondents $(33.3 \%$ ) followed by the 31 to 40 years of age category with an average of 46.22 years. The number of family members ranged from 3 to 14 with an average of 5.73, it was higher than the national average (4.2) [27] and the highest $(64.7 \%)$ portion of them fell under the 3 to 5 members category. The highest proportion of the respondents $(35.3 \%)$ had secondary level education followed by respondents who cannot read and write. A significant proportion of the respondents $(70.60 \%)$ possessed own land but $23.50 \%$ of them did not have any land. Most percentage of them $(60.8 \%)$ owned 0.01 to 3 acres of farm size with an average of 1.70 acres and it was less than the national average (1.97 acres) [28]. The highest proportion of the respondents $(37.3 \%)$ belonged to BDT 100001 to 200000 income category with an average of BDT 223686.27 and it was higher than the national average (BDT 159096) [29]. Most percentage of the respondents (37\%) kept contact with SAAOs (Sub-Assistant Agricultural Officers) followed by respondents with no extension media contact. The highest proportion of the respondents $(46.80 \%)$ fell in no training category and the remaining $53.2 \%$ of them received training on agriculturerelated issues.

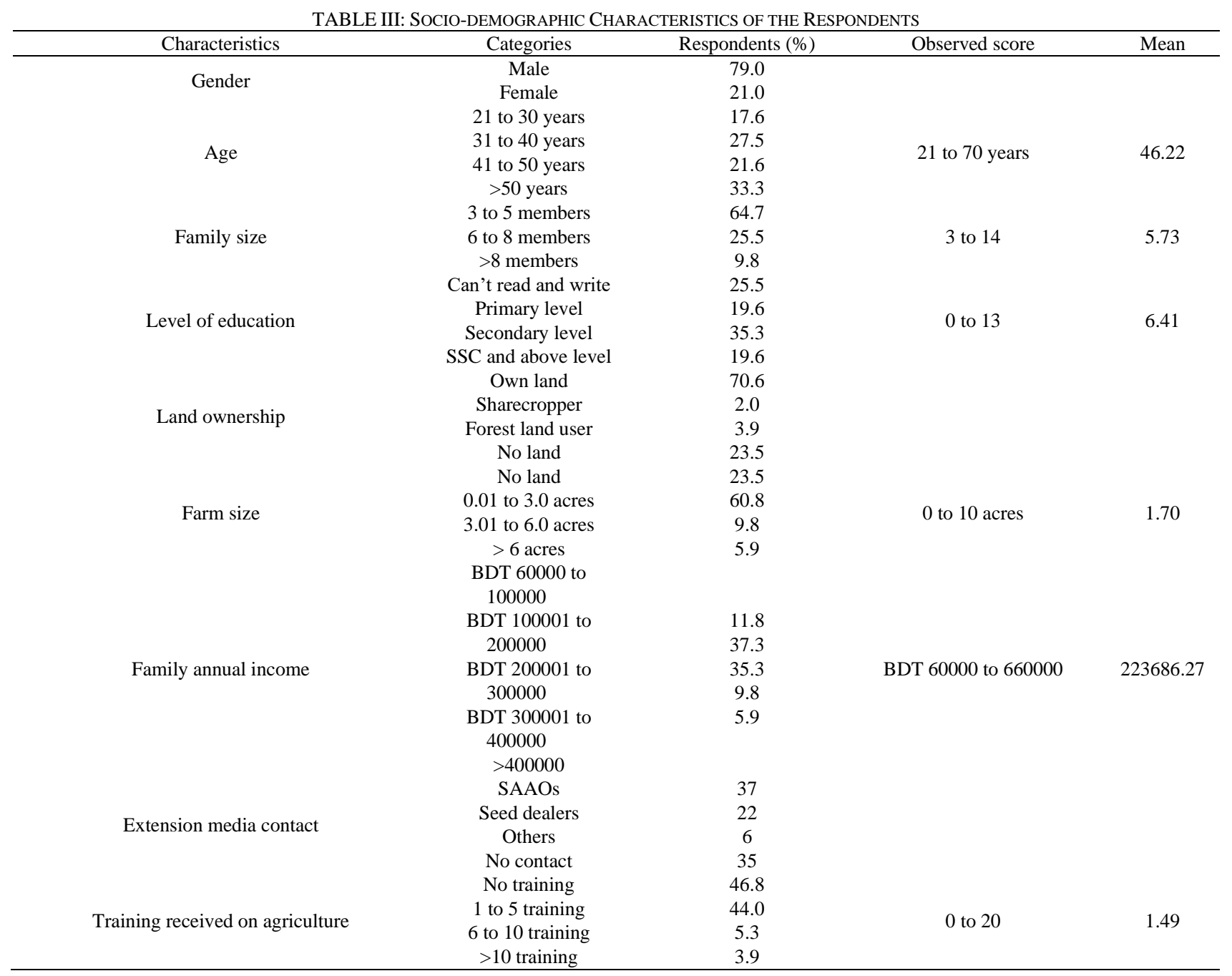

D. Contribution of the Selected Characteristics of the Respondents towards Their Perception of Ecosystem Services

This section explores the respondents' characteristics which contribute their perception towards ecosystem services. Regression results in Table IV indicated that three out of eight characteristics showed positive and significant contribution towards perception of ecosystem services. These are: 1) level of education, 2) family annual income, and 3) training received on agriculture. That means, the respondents with higher above-mentioned characteristics, perceived 
ecosystem services better than others and were more acquainted with the ecosystem conservation. These eight variables together explain $49.0 \%$ of the variation in the perception towards ecosystem services.

A study performed by [10] in Chittagong Hill Tracts, Bangladesh and observed that the respondents' level of education influenced their perception towards ecosystem. Similar types of findings were also observed by others [3032]. On the contrary, [33] witnessed that education had little or no influence on perception towards ecosystem services. [34] noticed that respondents with a high level of income perceived provisioning services more frequently than people with lower levels of income and [35] observed that the income of farmers had a significant influence on their perception towards ecosystem services. As reported by [36], training related to agriculture makes people more concerned about environment-related issues like climate change, adverse effects of human activities on the environment, etc. Thus, people with a higher number of agriculture-related training perceive ecosystem services better than others. Similar types of findings were also observed by Hasan et al., [25] where they found that training received of the farmers on agriculture influenced their response towards floating agriculture for sustainable development and food security.

TABLE IV: RESPONDENTS' CHARACTERISTICS AND THEIR CONTRIBUTION TOWARDS PERCEPTION OF ECOSYSTEM SERVICES

\begin{tabular}{lccc}
\hline \multicolumn{1}{c}{$\begin{array}{c}\text { Characteristics of the } \\
\text { respondents }\end{array}$} & Coefficient $\beta$ & $\mathrm{t}$ - value & $\begin{array}{c}p \\
\text { (significant) }\end{array}$ \\
\hline 1. Age & -0.023 & -0.183 & 0.856 \\
\hline 2. Family size & 0.045 & 0.372 & 0.712 \\
\hline 3. Level of education & $0.472 * *$ & 3.134 & 0.003 \\
\hline 4. Respondent type & -0.168 & -1.076 & 0.289 \\
\hline $\begin{array}{l}\text { 5. Ownership of cultivable } \\
\text { land }\end{array}$ & 0.031 & 0.222 & 0.826 \\
\hline $\begin{array}{l}\text { 6. Family annual income } \\
\text { 7. Extension media contact }\end{array}$ & $0.337 *$ & 2.506 & 0.016 \\
\hline $\begin{array}{l}\text { 8. Training received on } \\
\text { agriculture }\end{array}$ & 0.213 & 0.960 & 0.343 \\
\hline $\begin{array}{l}\text { Note: } \mathrm{R}=0.70, \mathrm{R}^{2}=0.49, \text { Adjusted } \mathrm{R}^{2}=0.37, \text { Critical Value of } \mathrm{F}=3.88, \\
* \mathrm{p}<0.05, \text { and } * * \mathrm{p}<0.01 .\end{array}$ & & 2.303 & 0.027 \\
\hline
\end{tabular}

\section{CONCLUSIONS}

Based on the above findings, the following conclusions were drawn:

1. A total number of 20 ecosystem services were identified. All of the services except crop cultivation showed a decreasing trend. Rapid population growth, deforestation, industrialization, urbanization, and pollution were the main contributing factors behind this decreasing trend of the services. About $83 \%$ of the respondents possessed moderately favorable perception towards ecosystem services. This might be due to majority of the respondents were forest dwellers (Garos).

2. A major part of the respondents were ethnic people (Garo). Most percentage of the respondents (79\%) of the study area were male, more than half $(54.9 \%)$ of them aged over 41 years. The average family size was 5.73 and most percentage of them $(35.30 \%)$ received secondary level education. About $70.60 \%$ of them possessed their land with an average of 1.70 acres of farm size. The average family annual income of the respondents was BDT 223686.27. Most often the respondents $(37 \%)$ maintained contact with SAAOs and around half of them $(53.2 \%)$ received training on agriculture-related issues. These could create a medium perception of the respondents towards ecosystem services. Furthermore, respondents' level of education, family annual income, and training received on agriculture were the contributing factors that influenced their perception towards ecosystem services. That means, the higher the abovementioned characteristics, the higher their perception towards ecosystem services.

\section{REFERENCES}

[1] G. Daily, Nature's Services: Societal Dependence on Natural Ecosystems, Island Press, 1997.

[2] Campos, F. Alpizar, B. Louman and J. A. Parrotta, in Forests in the Global Balance - Changing Paradigms, G. Mery, R. Alfaro, M. Kanninen and M. Lovobikov, Eds., International Union of Forest Research Organizations, 2005, pp. 97-116.

[3] G. N. Gouwakinnou, S. Biaou, F. G. Vodouhe, M. S. Tovihessi, B. K. Awessou and H. S. Biaou, "Local perceptions and factors determining ecosystem services identification around two forest reserves in Northern Benin," Journal of Ethnobiology and Ethnomedicine, vol. 15, no. 1, pp. 1-12, 2019.

[4] I. Bond, M. Grieg-Gran, S. Wertz-Kanounnikoff, P. Hazlewood, S. Wunder and A. Angelsen, Incentives to sustain forest ecosystem services: A review and lessons for REDD, UK: International Institute for Environment and Development, 2009.

[5] R. Seidl, T. A. Spies, D. L. Peterson, S. L. Stephens and J. A. Hicke, "Searching for resilience: addressing the impacts of changing disturbance regimes on forest ecosystem services," Journal of Applied Ecology, vol. 53, pp. 120-129, 2016.

[6] S. S. Hasan, L. Zhen, M. G. Miah, T. Ahamed and A. Samie, "Impact of land use change on ecosystem services: A review," Environmental Development, vol. 34, 2020.

[7] J. M. Maass, P. Blavanera, A. Castillo, G. Daily and H. Mooney, "Ecosystem services of tropical dry forests: Insights from long-term ecological and social research on the Pacific Coast of Mexico," Ecology and Society, vol. 10, pp. 1-17, 2005.

[8] MEA, Ecosystems and Human Well-being: Multiscale Assessment, Island Press, 2005.

[9] L. D. Bhatta, B. E. H. v. Oort, N. E. Stork and H. Baral, "Ecosystem services and livelihoods in a changing climate: Understanding local adaptations in the Upper Koshi, Nepal," International Journal of Biodiversity Science Ecosystem Services and Management, vol. 11, pp. 145-155, 2015.

[10] R. Ahammad, N. Stacey and T. C. Sunderland, "Use and perceived importance of forest ecosystem services in rural livelihoods of Chittagong Hill Tracts, Bangladesh," Ecosystem services, vol. 35, pp. 87-98, 2019.

[11] M. N. Hossain, M. Rokanuzzaman, M. A. Rahman, M. Bodiuzzaman and M. A. Miah, "Causes of Deforestation and Conservation of Madhupur Sal Forest in Tangail Region," Journal of Environmental Science and Natural Resources, vol. 6, no. 2, pp. 109-114, 2013.

[12] K. K. Islam, G. M. Rahman, T. Fujiwaraa and N. Satoa, "People's participation in forest conservation and livelihoods improvement: experience from a forestry project in Bangladesh," International Journal of Biodiversity Science, Ecosystem Services \&Management, vol. 9, pp. 30-43, 2013.

[13] S. Deka, O. P. Tripathi and A. Paul, "Perception-based assessment of ecosystem services of Ghagra Pahar forest of Assam, Northeast India," Geology, Ecology, and Landscapes, pp. 197-209, 2018.

[14] S. Dey, "Degrading forest environment and local Garo females in Modhupur Garh, Bangladesh," Unpublished M. Phil dissertation, Department of Geography and Environment, University of Dhaka, Dhaka, 2004.

[15] N. Muhammed, S. Chakma, M. H. Masum, M. M. Hossain and G. Oesten, "A case study on the Garo ethnic people of the Sal (Shorea robusta) forests in Bangladesh," International Journal of Social Forestry, vol. 4, no. 2, pp. 197-211, 2011.

[16] M. Jalil and M. Oakkas, "The family structure and cultural practices of Garo community in Bangladesh: An overview," Online International Journal of Arts and Humanities, vol. 1, no. 5, pp. 74-81, 2012. 
[17] S. S. Islam, "State of forest genetic resources conservation and management in Bangladesh," FAO, Italy, Working Paper FGR/68E, 2003.

[18] A. K. Paul, M. M. Mian, M. B. Khan and M. T. Islam, "Study on Biodiversity Conservation Practice in Madhupur Sal Forest, Bangladesh," Journal of Environmental Science and Natural Resources, vol. 6, no. 1, pp. 187-193, 2013.

[19] M. Rahman, A. Nishat and H. Vacik, "Anthropogenic disturbances and plant diversity of the Madhupur Sal forests (Shorea robusta CF Gaertn) of Bangladesh," International Journal of Biodiversity Science \& Management, vol. 5, no. 3, pp. 162-173, 2009.

[20] M. Alam, Y. Furukawa, S. Sarker and R. Ahmed, "Sustainability of Sal (Shorea robusta) Forest in Bangladesh: Past, Present and Future Actions," International Forestry Review, vol. 10, pp. 29-37, 2008.

[21] N. Salawat, S. S. Hasan, A. S. Khan, M. S. Rahman, M. M. Hoque and M. Moonmoon, "Study on knowledge and attitude of mushroom growers at selected upazilas of Dhaka," Bangladesh Journal of Mushroom, vol. 7, no. 1, pp. 49-57, 2013.

[22] M. K. Ghosh and S. S. Hasan, "Farmers' attitude towards sustainable agricultural practices," Bangladesh Research Publications Journal, vol. 8, no. 4, pp. 227-235, 2013.

[23] S. Chouichom and M. Yamao, "Comparing opinions and attitudes of organic and non-organic farmers towards organic rice farming system in north-eastern Thailand," Journal of Organic Systems, vol. 5, no. 1, pp. 25-35, 2010.

[24] S. S. Hasan, M. E. Haque, I. Z. Suchi and M. A. Hossain, "Assessment of Diploma Agricultural Students' Attitude towards Educational Sustainability: A Study of Selected Agricultural Training Institutes of Bangladesh," Journal of Education, Society and Behavioural Science, vol. 25, no. 2, pp. 1-12, 2018.

[25] S. S. Hasan, A. Mohammad, M. K. Ghosh and M. I. Khalil, "Assessing of farmers' opinion towards floating agriculture as a means of cleaner production: A case of Barisal district, Bangladesh," British Journal of Applied Science and Technology, vol. 20, no. 6, pp. 1-14, 2017.

[26] S. S. Hasan, M. K. Ghosh, M. S. Arefin and S. Sultana, "Farmers Attitude Towards Using Agro-Chemicals in Rice Production: A Case in Laxmipur District of Bangladesh," The Agriculturists, vol. 13, no. 2, pp. 105-112, 2015.

[27] BBS, Statistical Year Book of Bangladesh, Dhaka: Ministry of Planning, Government of Bangladesh, 2018.

[28] DAE, Agricultural Extension Manual, Dhaka: Department of Agricultural Extensiion, 2016, pp. 8.

[29] HIES (Household Income and Expenditure Survey), Bangladesh Bureau of Statistics, Dhaka, 2016.

[30] S. S. K. Scholte, A. J. A. Teeffelen and P. H. Verburg, "Integrating socio-cultural perspectives into ecosystem service valuation: A review of concepts and methods," Ecological Economics, vol. 114, pp. 67-78, 2015.

[31] F. Xun, Y. Hu, L. Lv and J. Tong, "Farmers' Awareness of Ecosystem Services and the Associated Policy Implications," Sustainability, vol. 9, pp. 1612, 2017.

[32] V. Caballero-Serrano, J. G. Alday, J. Amigo, D. Caballero, J. C. Carrasco, B. McLaren and M. Onaindia, "Social perceptions of biodiversity and ecosystem services in the Ecuadorian Amazon," Human Ecology, vol. 45, pp. 475-486, 2017.

[33] W. Zhang, E. Kato, P. Bhandary, E. Nkonya, H. I. Ibrahim, M. Agbonlahor and H. Y. Ibrahim, "Communities' Perceptions and Knowledge of Ecosystem Services," IFPRI Discussion Paper 01418, 2015.

[34] C. Quintas-Soriano, J. Brandt, C. V. B. K. Running, D. M. Gibson, J. Narducci and A. J. Castro., "Social-ecological systems influence ecosystem service perception: a programme on ecosystem change and society (PECS) analysis," Ecology and Society, vol. 23, pp. 3, 2018.

[35] J. He, X. B. Shu and X. B. Yu, "Surveys and analysis of farmers' perception about wetland ecosystem services in Poyang Lake," Resources Science, vol. 32, pp. 776-781, 2010.

[36] M. S. Islam, M. H. Kabir, M. S. Ali, M. S. Sultana and M. Mahasin, "Farmers' Knowledge on Climate Change Effects in Agriculture," Agricultural Sciences, vol. 10, no. 3, pp. 386, 2019. 